\title{
Novel Expression of GABA Receptors on Resistance Arteries That Modulate Myogenic Tone
}

\author{
Peter D. Yim ${ }^{a}$ George Gallos ${ }^{a}$ Steven A. Lee-Kong ${ }^{b}$ William Dan ${ }^{a}$ \\ Amy D. Wu ${ }^{a}$ Dingbang $\mathrm{Xu}^{\mathrm{a}}$ Dan E. Berkowitz ${ }^{\mathrm{C}}$ Charles W. Emala ${ }^{\mathrm{a}}$ \\ a Department of Anesthesiology, Columbia University, New York, NY, USA; ${ }^{b}$ Department of Surgery, \\ Columbia University, New York, NY, USA; ' ${ }^{2}$ eppartment of Anesthesiology and Perioperative Medicine, \\ University of Alabama, Birmingham, AL, USA
}

\section{Keywords}

Pressure myography $\cdot$ Membrane potential $\cdot$ Human omental artery - GABA - Resistance vessel - Myogenic tone

\begin{abstract}
The clinical administration of GABAergic medications leads to hypotension which has classically been attributed to the modulation of neuronal activity in the central and peripheral nervous systems. However, certain types of peripheral smooth muscle cells have been shown to express $G_{A B A}$ receptors, which modulate smooth muscle tone, by the activation of these chloride channels on smooth muscle cell plasma membranes. Limited prior studies demonstrate that nonhuman large-caliber capacitance blood vessels mounted on a wire myograph are responsive to $G A B A_{A}$ ligands. We questioned whether $G A B A_{A}$ receptors are expressed in human resistance arteries and whether they modulate myogenic tone. We demonstrate the novel expression of $\mathrm{GABA}_{\mathrm{A}}$ subunits on vascular smooth muscle from small-caliber human omental and mouse tail resistance arteries. We show that $G_{A B A}$ receptors modulate both plasma membrane potential and calcium responses in primary cultured cells from human resistance arteries. Lastly, we demonstrate functional physiolog-
\end{abstract}

ic modulation of myogenic tone via $G_{A B A}$ receptor activation in human and mouse arteries. Together, these studies demonstrate a previously unrecognized role for GA$B A_{A}$ receptors in the modulation of myogenic tone in mouse and human resistance arteries.

(c) 2020 S. Karger AG, Basel

\section{Introduction}

The prevalence of hypertension in the USA is greater than $30 \%$ in the adult population and the health care costs associated with hypertension are astronomical [1]. The direct correlation between hypertension and other comorbid states has made hypertension a risk factor for almost all leading causes of mortality [2,3] and morbidity [4-6]. As the population of patients with hypertension increases [2], new and effective therapies are needed to treat patients who are failing current therapies for hypertension.

It is well recognized that clinically used GABAergic anesthetics are associated with hypotension due to a decreased systemic vascular resistance. Mechanisms of GABAergic anesthetic-induced hypotension are thought to

\section{KARGER}

(c) 2020 S. Karger AG, Basel

karger@karger.com

www.karger.com/jvr
Dr. Peter D. Yim

Department of Anesthesiology

622 West 168th Street, P\&S Box 46

New York, NY 10032 (USA)

pdy1@columbia.edu 
include peripheral autonomic ganglion inhibition [7], central paraventricular nucleus inhibition [8], and baroreceptor inhibition [9]. However, these neuronal targets may not provide a complete mechanism of anestheticinduced hypotension. Furthermore, there has been growing evidence that GABAergic anesthetic-mediated vasorelaxation is due to direct activation of $\mathrm{GABA}_{\mathrm{A}}$ receptors on vascular smooth muscle (VSM) cells [10-14]. However, these studies were performed in large arteries or in cell cultures derived from these large vessels, neither of which are the physiologic determinants of blood pressure. The primary determinants of vascular resistance are small resistance arteries. These resistance arteries have not yet been evaluated for their intrinsic GABAergic response on myogenic tone or their $\mathrm{GABA}_{\mathrm{A}}$ receptor subunit expression.

$\mathrm{GABA}_{\mathrm{A}}$ receptors are ligand-gated, inhibitory chloride channels that are well characterized in the central nervous system (CNS). While their physiology and pharmacology have been extensively characterized in the CNS, they have only recently been appreciated to be functionally expressed on many peripheral cell types, including other non-VSM [15]. Classic $\mathrm{GABA}_{\mathrm{A}}$ receptors are heteropentamers containing a combination of 19 possible subunits $(\alpha[1-6], \beta[1-3], \gamma[1-3], \delta, \varepsilon, \theta, \pi$, and $\rho[1-3])$. $\mathrm{GABA}_{\mathrm{A}}$ channels containing the necessary subunits to form a functional channel have been previously described in airway smooth muscle [16]. Furthermore, activation of these $\mathrm{GABA}_{\mathrm{A}}$ receptor channels on airway smooth muscle cells increased chloride channel flux and attenuated calcium release into the intracellular compartment, leading to a direct decrease in airway smooth muscle tension $[15,17-23]$. Recognizing the vasodilatory effects of GABAergic anesthetics and the growing evidence of direct $\mathrm{GABA}_{\mathrm{A}}$-mediated smooth muscle relaxation, we hypothesize that $\mathrm{GABA}_{\mathrm{A}}$ receptors exist on VSM cells of small resistance arteries and have significant effects on resistance arterial tone and function.

\section{Materials and Methods}

\section{Materials}

Gabazine, NS1619, and $\mathrm{KCl}$ were obtained from Sigma (St. Louis, MO, USA). Muscimol, picrotoxin, and bicuculline were obtained from Tocris (Bristol, UK). Propofol was obtained from MP Biomedical (Santa Ana, CA, USA). The fluorescent potentiometric probe (FLIPR) membrane potential assay kit was obtained from Molecular Devices (Sunnyvale, CA, USA). Trypsin 0.05\%- EDTA and FURA-2 (calcium dye) were purchased from Invitrogen (Carlsbad, CA, USA). TRIzol reagent was obtained from Ambion (Austin, TX, USA). Immunoaffinity purified primary antibodies for the $\mathrm{GABA}_{\mathrm{A}}$ a 4 subunit (LS-C15) were obtained from Lifespan Biosciences (Seattle, WA, USA).

\section{Animals and Human Tissue}

All mouse protocols were approved by the Columbia University Institutional Animal Care and Use Committee. Mice were euthanized with i.p. pentobarbital. Mouse tail arteries (MTA) were obtained from 5- to 10-week-old C57/Bl6 wild-type mice of both sexes. The human omental tissue protocol was reviewed by the Columbia University Institutional Review Board (IRB) and was deemed not to be human subject research under 45 CFR 46. Adult human omental samples were received from discarded tissue during colorectal surgeries, and resistance arteries (80-120 $\mu \mathrm{m})$ were dissected under a dissecting microscope. This method of procurement used de-identified samples as per IRB review and therefore medical information regarding patients is not available.

\section{Cell Culture}

The adventitial layer was removed from human omental arteries (HOA) using forceps under a dissecting microscope. The lumen was opened and the inner endothelial layer was mechanically abraded to remove the endothelium and basement membrane. The remaining muscle layer was then dissociated using a Worthington Biochemical (Lakewood, NJ, USA) Papain Dissociation System with collagenase type $4(2$ units $/ \mathrm{mL})$ added during the digestion step. Digestion occurred at $37^{\circ} \mathrm{C}$ for $1 \mathrm{~h}$ under constant agitation by a rocker as per the manufacturer's protocol, which includes an ova mucoid gradient to isolate smooth muscle from other cell types. After isolation, the cells were grown to confluence in $75-\mathrm{cm}^{2}$ flasks and 96-well black-walled clear bottom plates for fluorescent FLIPR membrane potential assays. All cells were maintained in M199 media (Gibco-Thermofisher, Waltham, MA, USA) with or without additives (human recombinant fibroblast growth factor $1 \mathrm{ng} / \mathrm{mL}$, human recombinant epidermal growth factor $0.25 \mathrm{ng} /$ $\mathrm{mL}$, insulin $1 \mu \mathrm{g} / \mathrm{mL}$, transferrin $0.55 \mu \mathrm{g} / \mathrm{mL}$, selenium $0.67 \mathrm{ng} /$ $\mathrm{mL}$, and $10 \%$ fetal bovine serum) at $37^{\circ} \mathrm{C}$ in $95 \%$ air $/ 5 \% \mathrm{CO}_{2}$. Prior to all cell-based assays, primary VSM cells were maintained in serum- and additive-free M199 media (i.e., basal M199 media only) for $24 \mathrm{~h}$ prior to experimentation.

\section{Isolation of RNA and RT-PCR}

In experiments where RNA was isolated using laser capture microdissection (LCMD), mouse tail and human omental resistance arteries were embedded in OCT compound followed by isopentane/dry ice freezing. Frozen sections of $6 \mu \mathrm{m}$ thickness were made under RNase-free conditions and were placed on a single 1-mm PEN-membrane-coated slide (PALM Microlaser Technologies, Westchester, NY, USA) and processed using an LCMD staining kit (Ambion AM1935). Histologic and morphologic-guided laser dissection was performed, harvesting only central portions of smooth muscle to avoid contamination from other adjacent cell types using a PALM MicroBeam laser microscope. RNA was recovered from LCMD samples using an RNAqueous-micro kit (Ambion) according to manufacturer's recommendations (approx. $3 \mu \mathrm{g}$ total RNA was recovered per 5 million square microns). Recovered RNA was reverse transcribed into cDNA using a commercially available kit, SuperScript VILO (Invitrogen). LCMDcaptured RNA $(10 \mu \mathrm{L})$ in sample buffer was reverse transcribed using random hexamer primers at $42^{\circ} \mathrm{C}$ for $1 \mathrm{~h}$ in $20 \mu \mathrm{L}$, according to the manufacturer's recommendations. 
Newly synthesized cDNA $(5 \mu \mathrm{L})$ from RNA isolated by LCMD from MTA smooth muscle cells was used in PCR using the Advantage 2 Polymerase Kit (Clontech, Mountain View, CA, USA). Sense and antisense primers $(0.4 \mu \mathrm{M})$ were used for corresponding $\mathrm{GABA}_{\mathrm{A}}$ channel subunits (Table 1 ) and were designed within separate exons to span large introns to ensure that contaminating genomic DNA did not yield false positive PCR bands at the molecular size expected for cDNA amplification. Primers targeting GAP$\mathrm{DH}$ (Table 1) were used as a relative estimate of RNA quantity between tissue samples and to confirm RNA quality in each sample. All cDNA samples were denatured at $94^{\circ} \mathrm{C}$ for $10 \mathrm{~s}$. Annealing and extension temperatures were all $68^{\circ} \mathrm{C}$ for $1 \mathrm{~min}$. Each sample underwent 30-40 cycles of amplification in a PTC-200 Peltier thermal cycler (Bio-Rad, Hercules, CA, USA). PCR products were analyzed on a $5 \%$ non-denaturing polyacrylamide gel in Tris acetate, EDTA buffer. The gel was stained with ethidium bromide (Molecular Probes, Eugene, OR, USA) and visualized using a gel imager (Biospectra UVP, Upland, CA, USA) and Visionworks software (Biospectra UVP).

\section{Immunohistochemistry for $G A B A_{A} \alpha 4$ Subunit in $H O A$}

Omental artery tissue samples were dissected and fixed with $5 \%$ formalin for $4 \mathrm{~h}$ and stored in $70 \%$ ethanol. Following serial dehydration through a graded alcohol series, fixed tissues were then embedded in paraffin blocks and serial $6-\mu \mathrm{m}$ sections were placed on a glass microscope slide. The slide was then dewaxed and incubated in hydrogen peroxide (30\% in PBS) for $30 \mathrm{~min}$. After washing and permeabilization with $0.1 \%$ Triton-X, the slide was placed in $10 \%$ goat serum in PBS for $2 \mathrm{~h}$ at room temperature. Serum was removed and the slide was incubated with an immunoaffinity purified $\mathrm{GABA}_{\mathrm{A}}$ a 4 subunit-specific antibody (rabbit; LS-C15, LifeSpan BioSciences, Seattle, WA, USA; 1:100) in PBS overnight at $4{ }^{\circ} \mathrm{C}$. A serial section on the same slide was incubated under identical conditions except that the primary antibody was omitted. The slide was again washed and incubated with biotinylated goat antirabbit $\operatorname{IgG}(1: 80)$ in $10 \% \mathrm{BSA} / \mathrm{PBS}$ for $1 \mathrm{~h}$ at room temperature. Biotinylated antibodies were then stained and visualized using a VectaStain (Burlingame, CA, USA) ABC kit.

\section{Membrane Potential Measurements Using Fluorescent}

Potentiometric Dye

Human VSM cells were grown to $100 \%$ confluency in 96 -well black-walled clear-bottom plates. Cells were made serum- and growth factor-free for $24 \mathrm{~h}$ prior to the assay (in basal M199 medium). On the day of the assay, cells were washed with Kreb's buffer (140 mM NaCl/4.7 mM KCl/2.5 mM CaCl$/ 1.2 \mathrm{mM} \mathrm{MgCl}_{2} / 11 \mathrm{mM}$ HEPES/10 mM D-glucose, $\mathrm{pH}$ 7.4). FLIPR membrane potential blue dye was dissolved in Krebs buffer at the concentration of 1 vial (approx. $125 \mathrm{mg}$ ) in $100 \mathrm{~mL}$. Cells were incubated in $100 \mu \mathrm{L}$ of $50 \%$ dye for $20 \mathrm{~min}$ in a humidified $37^{\circ} \mathrm{C}$ cell culture incubator (95\% air $/ 5 \%$ $\mathrm{CO}_{2}$ ). Fluorescence was repetitively measured at 2 -s intervals in a prewarmed $\left(37^{\circ} \mathrm{C}\right.$ ) Flex Station 3 UV spectrophotometer (Molecular Devices) using an excitation wavelength of $530 \mathrm{~nm}$, an emission wavelength of $565 \mathrm{~nm}$, and a cutoff filter of $550 \mathrm{~nm}$. NS1619 $100 \mu \mathrm{M}$ (potassium channel opener causing hyperpolarization), $40 \mathrm{mM} \mathrm{KCl}$ (depolarizing agent), and $10 \mu \mathrm{M}$ propofol or $0.1 \%$ DMSO control was added at a single concentration using the automated injection feature of the spectrophotometer during continuous fluorescent readings. In some experiments bicuculline was added to the wells manually 5 min before propofol as a pretreatment.

Functional GABA $\mathrm{G}_{\mathrm{A}}$ Receptors on

Resistance Arteries
Intracellular Calcium Measurements Using a Fluorescent

Ratiometric Calcium Indicator

Primary cultures of HOA smooth muscle cells were grown to full confluence in black-walled, clear-bottomed, 96-well plates. The cells were made serum- and growth factor-free for $24 \mathrm{~h}$ prior to the assay (in basal M199 medium). They were washed with 100 $\mu \mathrm{L}$ (per well) of Hanks' balanced salt solution (HBSS) and then loaded with HBSS $(100 \mu \mathrm{L} /$ well) containing $2.5 \mu \mathrm{M}$ Fura-2 AM, before being incubated for $30 \mathrm{~min}$ at $37^{\circ} \mathrm{C}$. The wells were then washed with HBSS and an additional incubation step was performed for $30 \mathrm{~min}$ at $37^{\circ} \mathrm{C}\left(95 \%\right.$ air, $\left.5 \% \mathrm{CO}_{2}\right)$. The cells were then pretreated for 2 min with muscimol 1-100 $\mu \mathrm{M}$, propofol $0.1-10 \mu \mathrm{M}$ or vehicle ( $0.1 \%$ DMSO) before the addition of $50 \mathrm{nM}$ endothelin- 1 by use of the automatic injection feature of the FlexStation $3 \mathrm{mi}-$ croplate reader (Molecular Devices, Sunnyvale, CA, USA) during continuous fluorescent measurements (excitation $340 / 380 \mathrm{~nm}$ and emission $510 \mathrm{~nm}$ ). Real-time changes in intracellular $\mathrm{Ca}^{2+}$ are reported as RFU (relative fluorescence units).

\section{Electrophysiologic Recordings of VSM Using an Automated}

\section{Patch Clamp System}

Human VSM cells were dispersed into Kreb's buffer at a concentration of 5 million cells $/ \mathrm{mL}$ and cells were made serum- and growth factor-free for $24 \mathrm{~h}$ prior to the assay (in basal M199 medium). The cells were loaded into a SyncroPatch 96-well automated patch clamp system (Nanion, Munich, Germany) within a disposable loading plate with a medium resistance pore size. The cells were then placed into the automated patch system and a whole cell configuration with a transient use of seal enhancement buffer. The cells were continuously analyzed for the quality of the seal resistance and capacitance. The cells were then placed under a $-80-\mathrm{mV}$ voltage clamp and treated with $100 \mu \mathrm{M}$ muscimol. The currents were recorded in 4 - or 10 -s sweeps at a sample rate of $20 \mathrm{kHz}$. Pretreatments were programmed into the automation, where $50 \mu \mathrm{M}$ picrotoxin was added in the external solution or low chloride solution replaced the internal solution. Treatments were performed on cells that initially responded to muscimol and had seals within $>200 \mathrm{M} \Omega$. Internal solution in $\mathrm{mM}$ : $\mathrm{KCl} 110, \mathrm{NaCl} 10$, EGTA 20, HEPES10 [pH 7.2]. External solution in mM: $\mathrm{NaCl} 140, \mathrm{KCl} 4$, $\mathrm{MgCl}_{2} 1, \mathrm{CaCl}_{2}$ 2, glucose 5, Hepes 10 (pH 7.4). Seal enhancer solution in mM: $\mathrm{NaCl} 80, \mathrm{KCl} 3, \mathrm{MgCl}_{2} 10 \mathrm{CaCl}_{2}$, Hepes 10 (pH 7.4). Low chloride internal solution in $\mathrm{mM}$ : K-gluconate $110, \mathrm{NaCl} 10$, EGTA 20, HEPES 10 (pH 7.2).

\section{Resistance Artery Myogenic Tone Studies}

Arteries from mouse tail or human omentum were dissected, leaving the adventitia and endothelium intact. Mouse arteries of less than 110 microns in diameter were used, and human arteries less than 300 microns in diameter were used. Vessels were cannulated with glass micropipettes $(75-100 \mu \mathrm{m})$. The pipettes were mounted within a chamber that was continuously perfused with buffered solution (buffer used in human studies in mM: $118 \mathrm{NaCl}$, $5.6 \mathrm{KCl}, 2.5 \mathrm{CaCl}_{2}, 2.4 \mathrm{MgSO}_{4}, 1.3 \mathrm{NaH}_{2} \mathrm{PO}_{4}, 25 \mathrm{NaHCO}_{3}$, and 5.6 glucose, $\mathrm{pH} 7.4$; buffer used in murine studies in mM: $115 \mathrm{NaCl}$, $2.5 \mathrm{KCl}, 2.5 \mathrm{CaCl}_{2}, 2.4 \mathrm{MgSO}_{4}, 1.3 \mathrm{NaH}_{2} \mathrm{PO}_{4}, 25 \mathrm{NaHCO}_{3}$, and 5.6 D-glucose, $\mathrm{pH} 7.4)$ that was oxygenated $\left(95 \% \mathrm{O}_{2} / 5 \% \mathrm{CO}_{2}\right)$ and temperature controlled $\left(37^{\circ} \mathrm{C}\right)$. The micropipettes were connected to a peristaltic pump manually controlled to provide a constant intraluminal pressure. The wall diameter was monitored by video edge detection, measuring smooth muscle isotonic contraction or 
Table 1. Sense and antisense primers

\begin{tabular}{|c|c|c|c|c|}
\hline Gene & Access No. & Sequence $\left(5^{\prime}\right.$ to $\left.3^{\prime}\right)$ & $\begin{array}{l}\text { cDNA } \\
\text { product }\end{array}$ & $\begin{array}{l}\text { gDNA } \\
\text { product }\end{array}$ \\
\hline \multicolumn{5}{|c|}{ Human GABR subunit RT-PCR primer sequence } \\
\hline GABRA1 & NM_000806 & $\begin{array}{l}\text { GAAGAGAAAGATTGGCTACTTTGTTATTCAAACAT } \\
\text { GAGCGTAAGTGTTGTTTTTCTTAATAAGAGGAT }\end{array}$ & 371 & 6,268 \\
\hline GABRA2 & NM_000807 & $\begin{array}{l}\text { TCTGCCCTAATTGAATTTGCAACTGTTAATTACTT } \\
\text { CTATTCTGGACATTCTGTCAATTTTGCTAACACTG }\end{array}$ & 295 & 11,616 \\
\hline GABRA3 & NM_000808 & $\begin{array}{l}\text { CACTTCCATCTCAAGCGAAAAATTGGCTACTTTGT } \\
\text { CCCACGATGTTGAAGGTAGTGCTGGTTTTCT }\end{array}$ & 398 & 29,255 \\
\hline GABRA4 & NM_000809 & $\begin{array}{l}\text { CAAACCGTATCAAGTGAAACCATCAAATCAAT } \\
\text { GCTTAGTGTGGTCATGGTGAGGACAGTTGTTAT }\end{array}$ & 225 & 9,074 \\
\hline GABRA5 & NM_000810 & $\begin{array}{l}\text { GCAGACGGTGGGCACTGAGAACA } \\
\text { GATAAGATCACGGTCATTATGCAGGGAAGGTA }\end{array}$ & 138 & 2,734 \\
\hline GABRA6 & NM_000811 & $\begin{array}{l}\text { CAGTGACAATATCAAAAGCTACTGAACCTTTGGAA } \\
\text { AATCCTGCAAATGCAACTGGGAAGAGAA }\end{array}$ & 259 & 9,556 \\
\hline GABRB1 & NM_000812 & $\begin{array}{l}\text { TCGCACTAGGAATCACGACGGTGCTTA } \\
\text { GAGCCACTCGTCTCATTCCGGATTT }\end{array}$ & 316 & 19,063 \\
\hline GABRB2 & NM_021911 & $\begin{array}{l}\text { GCTGCCAGTGCCAACAATGAGAAGA } \\
\text { TGGGGGTCCATCGTATACAGAGAGAAA }\end{array}$ & 170 & 4,571 \\
\hline GABRB3 & NM_000814 & $\begin{array}{l}\text { TCACAACTGTGCTGACAATGACAACCATCAAC } \\
\text { TAATTTTGAGCTGTGAAGACCTCCTCCGTAGA }\end{array}$ & 474 & 13,271 \\
\hline GABRG1 & NM_173536 & $\begin{array}{l}\text { CTTTCCCATGGATGAACATTCCTGTCCACTGGAATTTT } \\
\text { CAGGCACTGCATCTTTATTGATCCAAAAAGACACCC }\end{array}$ & 320 & 6,253 \\
\hline GABRG2 & NM_198904 & $\begin{array}{l}\text { AGGTCTCCTATGTCACAGCGATGGATCTCT } \\
\text { GACACTCATAGCCGTACTCTTCATCTCTCTCT }\end{array}$ & 267 & 4,022 \\
\hline & NM_198903 & $\begin{array}{l}\text { AGGTCTCCTATGTCACAGCGATGGATCTCT } \\
\text { GACACTCATAGCCGTACTCTTCATCTCTCTCT }\end{array}$ & 243 & 4,022 \\
\hline GABRG3 & NM_033223 & $\begin{array}{l}\text { GACCTGGACAGATAGTCGCCTTCGATTCAACAGCACAA } \\
\text { TCTGTGGTGTTTCTGAGGCCCATGAAGTCAAACTGATA }\end{array}$ & 393 & 153,930 \\
\hline GAPDH & NM_002046 & $\begin{array}{l}\text { CCAGGGCTGCTTTTAACTCTGGTAAAGTGGATA } \\
\text { CATCGCCCCACTTGATTTTGGAGGGA }\end{array}$ & 213 & 432 \\
\hline Mouse GA & S & ner sequence & & \\
\hline GABRA1 & NM_010250 & $\begin{array}{l}\text { CTATGGACAGCCCTCCCAAGATGAACTTA } \\
\text { GTGACGAAAATGTCGGTCTTCACTTCAGTTA }\end{array}$ & 147 & 13,427 \\
\hline GABRA2 & NM_008066 & $\begin{array}{l}\text { GAACAGAGAATCGGTGCCAGCAAGA } \\
\text { TGCAAATTCAATTAGGGCAGAGAACACAA }\end{array}$ & 175 & 32,654 \\
\hline GABRA3 & NM_008067 & $\begin{array}{l}\text { GGTTCATAGCCGTCTGTTATGCCTTTGTA } \\
\text { GTTTTTCTTTGTTGGAGCTGCTGGTGTTT }\end{array}$ & 158 & 10,348 \\
\hline GABRA4 & NM_010251 & $\begin{array}{l}\text { CCTGTGCTGAAGGAGAAACACACAGAA } \\
\text { GAATGGATTTGGACTGGAAGCTAAGTG A }\end{array}$ & 210 & 51,841 \\
\hline GABRA5 & NM_176942 & $\begin{array}{l}\text { TGCTATGCATTTGTCTTCTCTGCTCTGATT } \\
\text { GGAGGATGGGTCAGCTTTCCAGTTGTAA }\end{array}$ & 182 & 4,859 \\
\hline GABRA6 & NM_008068 & $\begin{array}{l}\text { GTCTGAATCCCTGCAAGCAGAGATTGTT } \\
\text { TTTAAGATGGGCGTTCTACTGAGGGCT TT }\end{array}$ & 138 & 7,544 \\
\hline GABRB1 & NM_008069 & $\begin{array}{l}\text { TGTCGCCAGCATAGACATGGTCTCGGAA } \\
\text { TCAGCTACTCTGTTGTCAAGGGTCAGAT }\end{array}$ & 138 & 168,664 \\
\hline GABRB2 & NM_008070 & $\begin{array}{l}\text { GGGTGCCTGACACCTACTTCCTGAATGATA } \\
\text { CAGTTTTGTTCATCCAGTGGATACCGCCTT }\end{array}$ & 175 & 41,666 \\
\hline GABRB3 & NM_008071 & $\begin{array}{l}\text { TACCACCGTGCTCACCATGACAACCATCAAC } \\
\text { TTTGATTTTGAGCTGTGAAGACCTCCTCCGT }\end{array}$ & 475 & 8,373 \\
\hline GABRD & NM_008072 & $\begin{array}{l}\text { CCAGTTCACTATCACCAGTTACCGCTTCAC } \\
\text { GCGTTCCTCACATCCATCTCTGCCCTT }\end{array}$ & 441 & 1,292 \\
\hline GABRE & NM_017369 & $\begin{array}{l}\text { CACATGCTCAATTTTCCAATGGATTCTCACTCTT } \\
\text { AGCGTGGCCATGGTGAGCACAGAACTGAC }\end{array}$ & 377 & 5,545 \\
\hline GABRG1 & NM_010252 & $\begin{array}{l}\text { GGAATACGGAACCTTGCATTATTTTACTAGCAACA } \\
\text { CAAACACTGGTAGCCATAATCATCTTCCCCTT }\end{array}$ & 175 & 20,154 \\
\hline GABRG2 & NM_008073 & $\begin{array}{l}\text { GACGCTGTGGATTCTGCTCCTGCTAT } \\
\text { CTCTGGAACTTTTGGAGTCAACACCCAT }\end{array}$ & 121 & 23,665 \\
\hline GABRG3 & NM_008074 & $\begin{array}{l}\text { GCCAGCTGCAACTGCATAACTTCCCT } \\
\text { AGTCAAACTGATAGAGCCGCCATGAT }\end{array}$ & 156 & 209,406 \\
\hline GABRP & NM_146017 & $\begin{array}{l}\text { GAGAACCTGCATTGGAGTGACAACGGTGTTA } \\
\text { AGTTGACATTGTCACCAGAGATTTCAATGCT }\end{array}$ & 320 & 1,771 \\
\hline GABRQ & NM_020488 & $\begin{array}{l}\text { CTGTTCCCTGGATCTGCAAAAATTCCCTATGGAC } \\
\text { TACCCTGGCTGCAGAGGAATCATAGTTCATCCAA }\end{array}$ & 346 & 1,191 \\
\hline GAPDH & NM_008084 & $\begin{array}{l}\text { CCGTAGACAAAATGGTGAAGGTCGGTGTGAA } \\
\text { CAATGAAGGGGTCGTTGATGGCAACAAT }\end{array}$ & 120 & 1,954 \\
\hline
\end{tabular}


relaxation (Living Systems, St. Albans, VT, USA). The arteries were exposed to 3 cycles of an acute rapid increase in intraluminal pressures from $0 \mathrm{~mm} \mathrm{Hg}$ and held for $2 \mathrm{~min}$ at a higher intraluminal pressure; $90 \mathrm{~mm} \mathrm{Hg}$ for mouse and $120 \mathrm{~mm} \mathrm{Hg}$ for human, at which time the vessel diameter was measured. Once a control myogenic contraction was established, the resistance arteries were exposed to $\mathrm{GABA}_{\mathrm{A}}$ modulators and rechallenged for 3 cycles with increasing luminal pressure $(0-90 \mathrm{~mm} \mathrm{Hg}$ for mouse and $0-120$ $\mathrm{mm} \mathrm{Hg}$ for human). The 3rd and 6th myogenic challenge under the control or experimental conditions were compared. Time (buffer) and vehicle controls (DMSO) were performed to verify the consistency between the 3rd and 6th myogenic tone challenge. $\mathrm{GABA}_{\mathrm{A}}$ modulators included muscimol $\left(100 \mu \mathrm{M}\right.$; specific $\mathrm{GABA}_{\mathrm{A}}$ agonist), gabazine (100 $\mu \mathrm{M}$; specific $\mathrm{GABA}_{\mathrm{A}}$ antagonist), propofol $\left(0.1 \mu \mathrm{M}\right.$ IV anesthetic with $\mathrm{GABA}_{\mathrm{A}}$ agonist effects) in $0.1 \%$ DMSO. The myogenic tone was measured at maximal constriction within the $5 \mathrm{~min}$ of increased intraluminal pressure. Studies were performed with $100 \mu \mathrm{M}$ gabazine alone to demonstrate the effects of $\mathrm{GABA}_{\mathrm{A}}$ antagonism on baseline tone in MTA. At an intraluminal pressure of $90 \mathrm{~mm} \mathrm{Hg}$, diameters before and after 5 min of treatment of gabazine were digitally collected. Pressures of 90 and 120 $\mathrm{mm} \mathrm{Hg}$ for myogenic tone measurements were chosen based on two reasons. Firstly, these pressures have been demonstrated in multiple prior studies to cause a large magnitude stretch-induced vessel contraction (myogenic tone) [24-27]. Secondly, intraluminal pressures in these higher ranges will achieve the force generation that occurs during hypertension, allowing for an assessment as to whether $\mathrm{GABA}_{\mathrm{A}}$ receptors have a significant effect on myogenic tone within hypertension ranges.

\section{Statistical Analyses}

Each experimental permutation included intraexperimental vehicle controls. In the fluorescence membrane potential, calcium indicator, and electrophysiology experiments, we employed oneway ANOVA with Bonferroni post test comparisons between appropriate groups. In the myogenic tone studies, a 2-tailed paired Student's $t$ test was employed. Data are presented as means \pm SEM. $p<0.05$ was considered significant in all cases.

\section{Results}

\section{RT-PCR Survey of GABA $A_{A}$ Subunits in Human and}

\section{Mouse Resistance Arterial Vascular Smooth Muscle}

To evaluate the expression profile of $\mathrm{GABA}_{\mathrm{A}}$ receptor subunits in resistance arteries, MTA smooth muscle samples and HOA samples were analyzed for the expression of mRNAs encoding $\mathrm{GABA}_{\mathrm{A}}$ subunits (Fig. 1). LCMD was used to histologically identify and selectively capture vascular smooth muscle (Fig. 1a). From these target tissue samples, RNA was extracted for RT-PCR (reverse transcription polymerase chain reaction). The PCR results demonstrate the expression of mRNA encoding the $\alpha 3$, $\alpha 4, \beta 2, \gamma 2$, and $\delta \mathrm{GABA}_{\mathrm{A}}$ subunits in MTA smooth muscle (Fig. $1 \mathrm{~b} ; n=3$ ), and $\alpha 4, \beta 2$, and $\delta \mathrm{GABA}_{\mathrm{A}}$ subunits in HOA smooth muscle (Fig. 1 c; $n=4$ ). All negative control water blank samples (no input RNA) did not yield any PCR products (data not shown) and all positive control brain (mouse and human, respectively) samples yielded PCR products of the expected molecular size. RT-PCR products using primers against GAPDH demonstrate the relative loading amounts of RNA from vascular smooth samples and brain samples in both human and mouse experiments (Fig. 1b, c). GABA $A_{A}$ subunits $\alpha 1, \alpha 2, \alpha 5, \alpha 6, \beta 1$, $\beta 3, \gamma 1$, and $\gamma 3$ were not detected in RNA isolated from either mouse tail or human omental arteries (data not shown) despite detecting their expected cDNA products in the brain positive control tissues. To confirm the specificity of $\mathrm{GABA}_{\mathrm{A}}$ subunit expression in resistance arterial VSM and to demonstrate the protein expression of the $\mathrm{GABA}_{\mathrm{A}}$ a 4 subunit, immunohistochemistry on human omental resistance arteries was performed. A longitudinally sectioned omental artery demonstrating dense brown staining representing $\mathrm{GABA}_{\mathrm{A}} \alpha 4$ protein expression was evident in the smooth muscle layer (Fig. $1 \mathrm{~d} ; n=$ $3)$. The control serial section with primary antibody omitted was devoid of significant brown staining ( $n=$ number of mice or patients).

\section{$G A B A_{A}$ Receptor Modulation of Plasma Membrane Potential in Arterial Smooth Muscle Cells}

To demonstrate the function of $\mathrm{GABA}_{\mathrm{A}}$ channels in primary VSM cells, the cells were loaded with the FLIPR potentiometric dye. Propofol (100 nM), an intravenous anesthetic with known $\mathrm{GABA}_{\mathrm{A}}$ activity, induced a depolarizing change in membrane potential demonstrated by an increase in FLIPR fluorescence $(p<0.01$ compared to $0.1 \%$ DMSO control; $n=4$; Fig. 2a, b). Furthermore, the change in membrane potential induced by propofol was inhibited by pretreatment with a $\mathrm{GABA}_{\mathrm{A}}$-specific inhibitor, bicuculline $(10 \mu \mathrm{M} ; p<0.05$ compared to $100 \mathrm{nM}$ propofol; $n=5$ ), indicating that the change in membrane potential induced by propofol was via $\mathrm{GABA}_{\mathrm{A}}$ receptor activation. $\mathrm{KCl}(40 \mathrm{mM})$ was used as a positive control for depolarization ( $p<0.01$ compared to $0.1 \%$ DMSO control; $n=8$ ). NS1619 (potassium channel activator; 10 $\mu \mathrm{M})$ was used as a hyperpolarization control $(p<0.05$ compared to $0.1 \%$ DMSO control; $n=8$; Fig. $2 \mathrm{a}$, b). The data were analyzed by comparing the absolute maximal fluorescence change compared to the DMSO vehicle control.

\section{$G A B A_{A}$ Receptor Modulation of Intracellular Calcium} in Arterial Smooth Muscle Cells

To demonstrate the effects of $\mathrm{GABA}_{\mathrm{A}}$ receptor activation on intracellular calcium responses in cultured hu- 

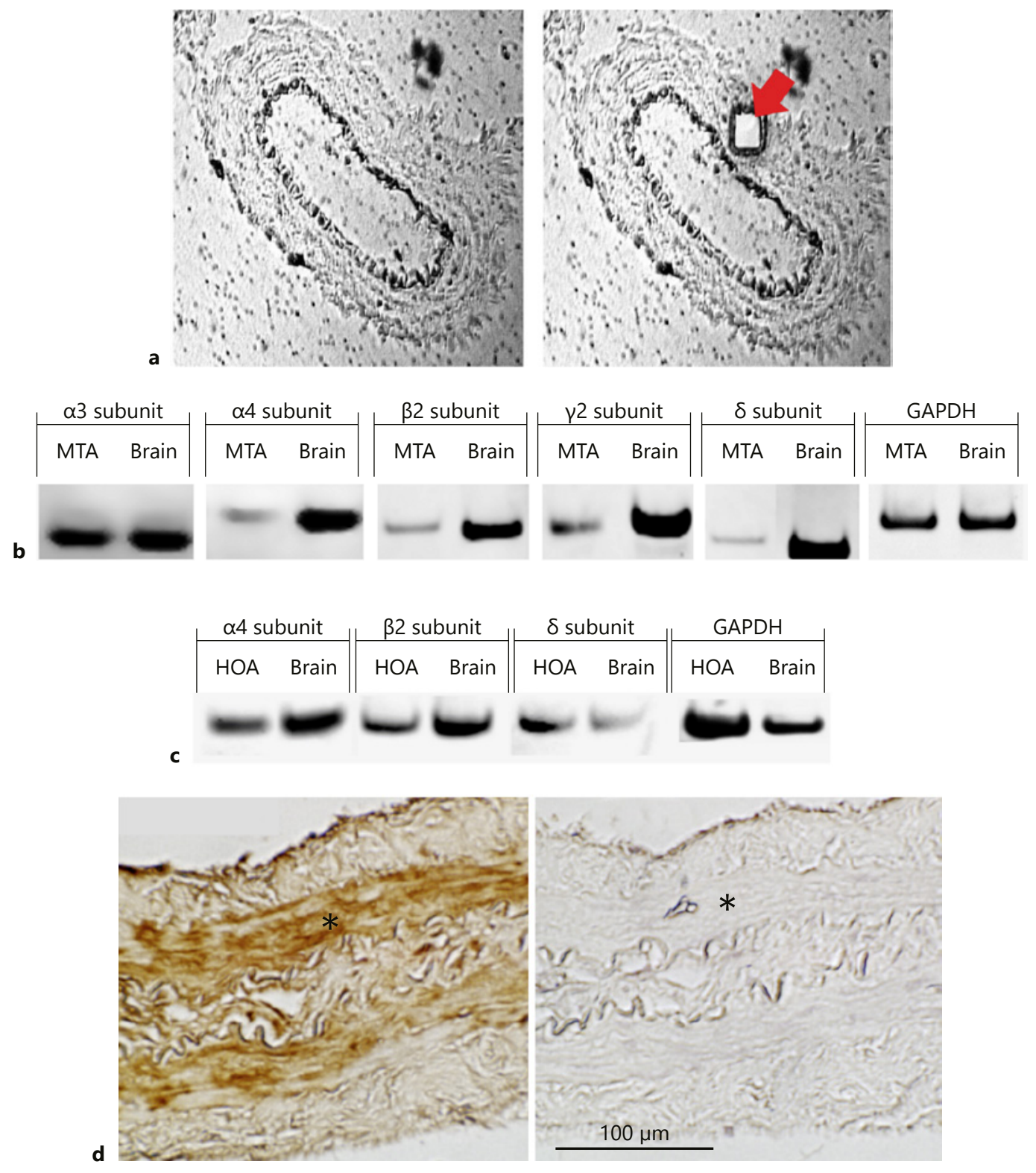

Fig. 1. a Representative images of OCT-embedded MTA sections. The smooth muscle layer was morphologically identified before (left image) RNA was captured from VSM cells using LCMD. The area excised is indicated by the red arrow in the right image. Representative gel images of RT-PCR products from LCMD-excised VSM from MTA (b) or HOA (c) using primers targeting mRNA encoding different $\mathrm{GABA}_{\mathrm{A}}$ subunits. RNA extracted from whole brain from mouse and human, respectively, served as positive con- trols. Primers targeting GAPDH mRNA demonstrate the relative mRNA input from brain versus VSM. d Representative light microscopic images of a longitudinal section of HOA labeled with a primary rabbit antibody targeted against human $\mathrm{GABA}_{\mathrm{A}}$ receptor a4 subunit (brown staining; left panel). The VSM layer is denoted by an asterisk. A control serial section of HOA in which the primary antibody was omitted during immunohistochemistry is shown (right panel). 

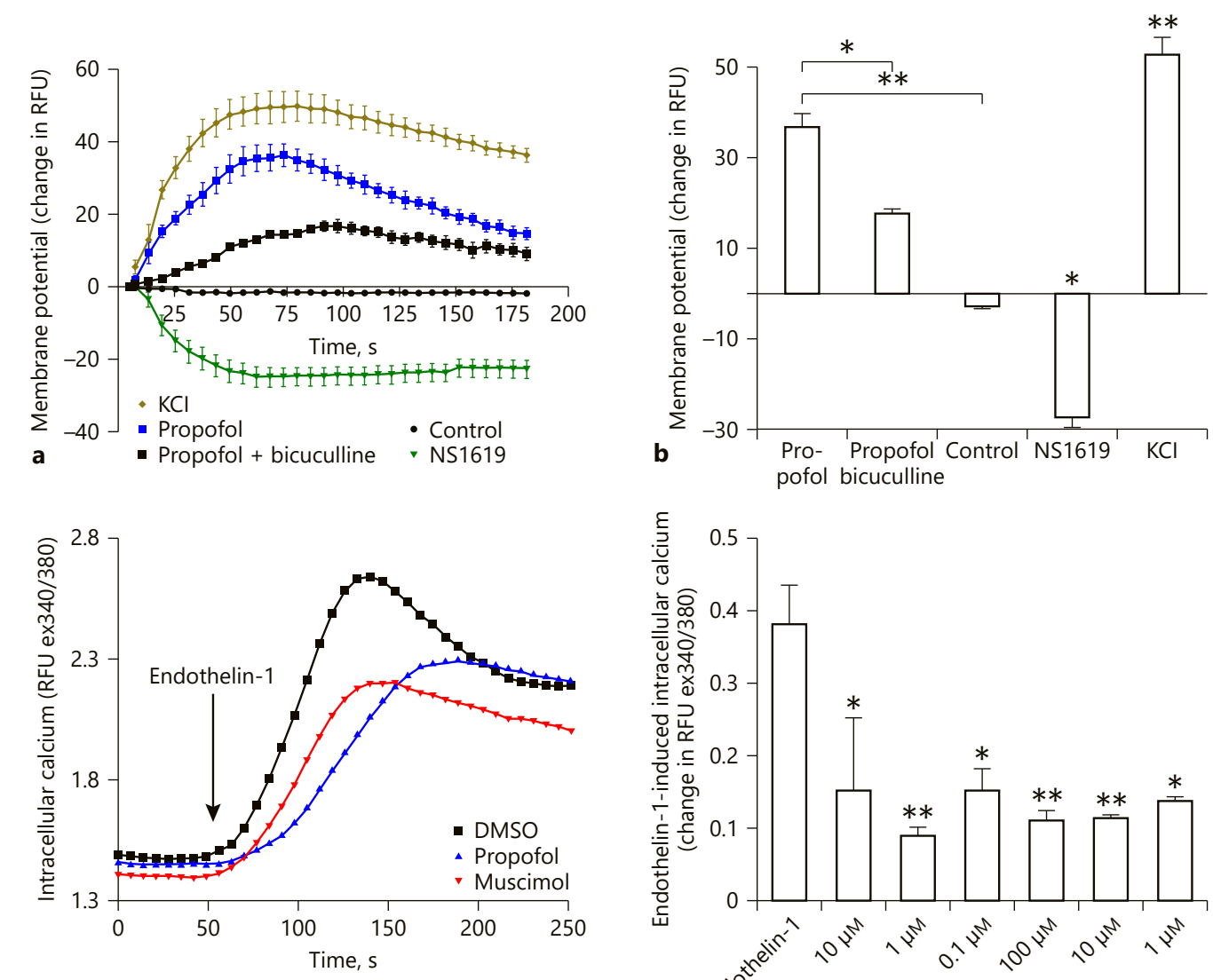

C

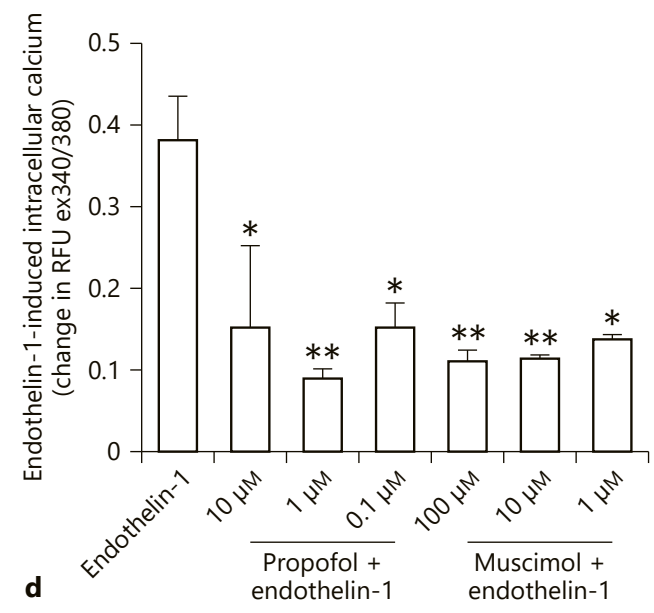

Fig. 2. a Aggregate tracing of the change in fluorescence in primary cell cultures of human omental VSM cells loaded with potentiometric dye (FLIPR). Fluorescence was continuously measured as $40 \mathrm{mM} \mathrm{KCl}, 100 \mathrm{nM}$ propofol, $100 \mu \mathrm{M} \mathrm{NS1619}$, or $0.1 \%$ DMSO was added. b Graphical representation of RFU changes during treatments of airway smooth muscle loaded with FLIPR dye. Propofol at $100 \mathrm{nM}$ demonstrated a $36 \pm 3.2 \Delta \mathrm{RFU}$ (mean \pm SEM; ${ }^{* *} p<0.01$ compared to control; $n=4$ ), which was significantly inhibited by $10 \mu \mathrm{M}$ of bicuculline $\left(\mathrm{GABA}_{\mathrm{A}}\right.$-specific inhibitor; $18 \pm 1.3 \Delta \mathrm{RFU}^{*}{ }^{*} p<0.05$ compared to $100 \mathrm{nM}$ propofol; $n=$ 3); $40 \mathrm{mM} \mathrm{KCl}$ induced a $53 \pm 4.1 \Delta \mathrm{RFU}\left({ }^{* *} p<0.01\right.$ compared to control; $n=7$ ). As a hyperpolarization control, $10 \mu \mathrm{M}$ NS1619 (potassium channel activator) was used and demonstrated a $-27 \pm 2.7$ $\Delta \mathrm{RFU}$ ( $* p<0.05$ compared to control; $n=7$ ). As a vehicle control, $0.1 \%$ DMSO vehicle demonstrated a $-2.5 \pm 0.66 \Delta \mathrm{RFU}(n=7)$. c A representative tracing of intracellular calcium fluorescence in freshly dispersed human omental VSM cells preincubated with calcium ratiometric dye (Fura-2). Cells were stimulated with $50 \mathrm{nM}$ endothelin- 1 at $50 \mathrm{~s}$. In cells pretreated with vehicle ( $0.1 \%$ DMSO) for $2 \mathrm{~min}$, endothelin-1 induced an acute increase in calcium-mediated fluorescence that was attenuated by pretreatment with either $100 \mathrm{nM}$ propofol or $100 \mu \mathrm{M}$ muscimol pretreatment. d Graphical representation of ratiometric fluorescence values of Fura2-loaded human omental resistance arterial smooth muscle cells. Endothelin-1 in the presence of $0.1 \%$ DMSO vehicle demonstrated a ratiometric increase of $0.38 \pm 0.06 \Delta \mathrm{RFU}(\operatorname{ex} 340 / 380 ; n=3)$. Propofol at 10,1 , and $0.1 \mu \mathrm{M}$ decreased endothelin responses to 0.15 $\pm 0.10,0.09 \pm 0.01$, and $0.15 \pm 0.03 \Delta \mathrm{RFU}(\mathrm{ex} 340 / 380)$, respectively $\left({ }^{*} p<0.05\right.$ and ${ }^{* *} p<0.01$, respectively, when compared to endothelin-1 alone; $n=4$ ). Muscimol at 100, 10, and $1 \mu \mathrm{M}$ decreased the endothelin- 1 response to $0.11 \pm 0.01,0.11 \pm 0.01$, and $0.14 \pm$ $0.01 \triangle \mathrm{RFU}(\mathrm{ex} 340 / 380)$, respectively $\left(* p<0.05\right.$ and ${ }^{* *} p<0.01$, respectively, when compared to endothelin-1 alone; $n=4$ ). 

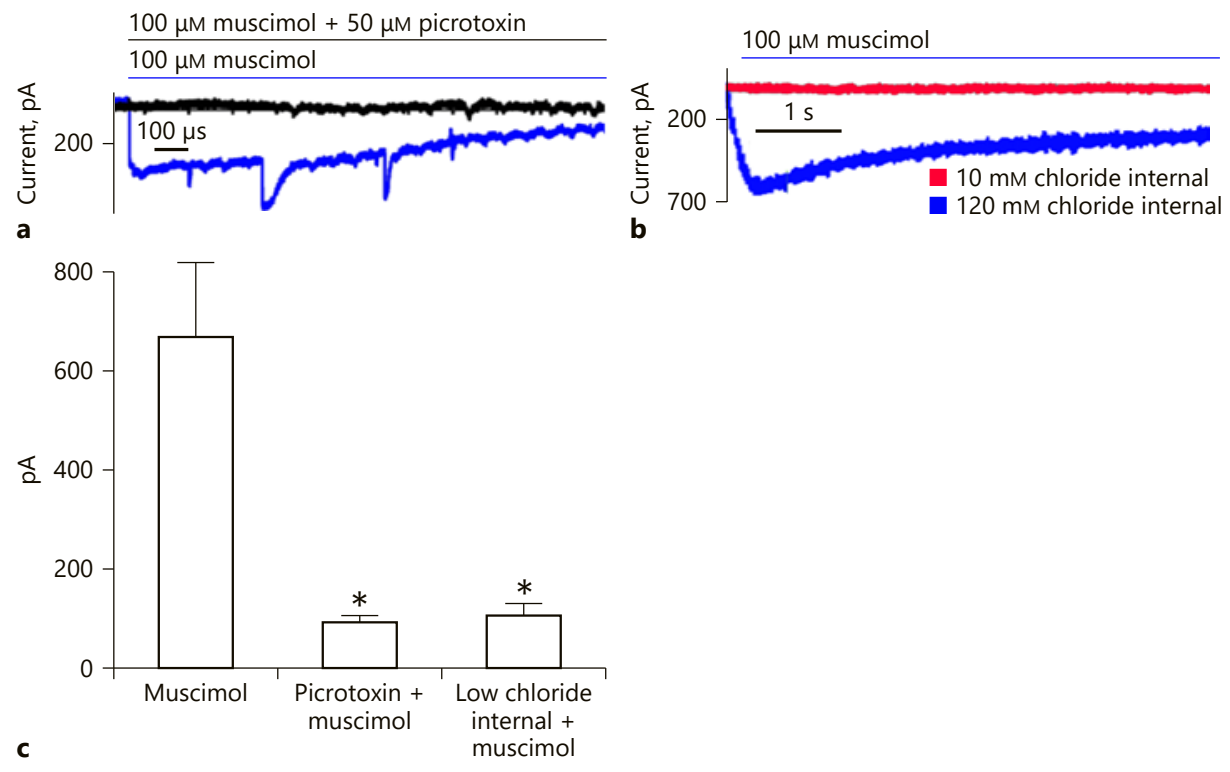

Fig. 3. Representative electrophysiologic recordings of human omental vascular cells using an automated patch clamp system. Cells were held in a voltage clamp configuration with a holding potential at $-80 \mathrm{mV}$. Picrotoxin $(50 \mu \mathrm{M})$ inhibited muscimol (100 $\mu \mathrm{M})$-induced currents (a), and decreasing the chloride internal concentration from 120 to $10 \mathrm{mM}$ also inhibited muscimol-in-

man resistance arterial smooth muscle cells, the cells were pretreated with the GABAergic anesthetic propofol or the classic $\mathrm{GABA}_{\mathrm{A}}$ agonist muscimol before a subsequent challenge with endothelin-1, a known vasoconstrictor. The cells were treated with propofol $(0.1-10 \mu \mathrm{M})$ or muscimol $(1-100 \mu \mathrm{M})$ for $2 \mathrm{~min}$ before treatment with endothelin-1 (50 nM). Endothelin-1 alone in the presence of $0.1 \%$ DMSO vehicle demonstrated a ratiometric increase of $0.38 \pm 0.06 \Delta \mathrm{RFU}$ (mean $\pm \mathrm{SEM} ; n=3$ ), indicating an increase in the intracellular concentration of calcium (Fig. 2c, d). Pretreatment with propofol at 10, 1, and 0.1 $\mu \mathrm{M}$ decreased endothelin-1-induced calcium responses $(p<0.05, p<0.01$, and $p<0.05$, respectively, compared to endothelin-1 alone; $n=4$; Fig. $2 \mathrm{~d}$ ). The classic $\mathrm{GABA}_{\mathrm{A}}$ receptor ligand, muscimol, at 100, 10, and $1 \mu \mathrm{M}$ decreased the endothelin- 1 calcium responses $(p<0.01, p<0.01$, $p<0.05$, respectively, compared to endothelin-1 alone; $n=4$; Fig. 2d). duced currents (b). c Graphical representation of current induced by muscimol $(669 \pm 149 \mathrm{pA}$ [mean $\pm \mathrm{SEM}] ; n=6)$. Muscimol currents were significantly reduced in the presence of picrotoxin ( 94.7 $\pm 12.7 \mathrm{pA} ; p<0.05$ compared to muscimol; $n=3)$ and also reduced by low internal chloride concentrations $\left(104 \pm 26.2 \mathrm{pA} ;{ }^{*} p<0.05\right.$ when compared to muscimol; $n=3$ ).

\section{Electrophysiologic Recordings of Human Arterial Smooth Muscle Cells Using an Automated Patch Clamp System}

To quantify the electrophysiologic responses of GA$\mathrm{BA}_{\mathrm{A}}$ channel activation in human omental resistance arterial smooth muscle cells, electrical current recordings were performed using an automated patch clamp system. Primary cultured cells of resistance arterial smooth muscle demonstrated inward current responses to $100 \mu \mathrm{M}$ muscimol (Fig. $3 ; n=6$ ). A muscimol response was demonstrated in $10 \%$ of cells patched in culture. To demonstrate the specificity of the muscimol response, the muscimol-induced currents were inhibited by the $\mathrm{GABA}_{\mathrm{A}^{-}}$ specific inhibitor picrotoxin $(p<0.05$ compared to muscimol alone; $n=3$; Fig. 3a, c). Furthermore, to demonstrate that the $\mathrm{GABA}_{\mathrm{A}}$ response was indeed a chloride current, the internal solution was changed to a low chloride composition (by replacing $\mathrm{KCl}$ with $\mathrm{K}$-gluconate) reducing the internal chloride concentration from 120 to 10 


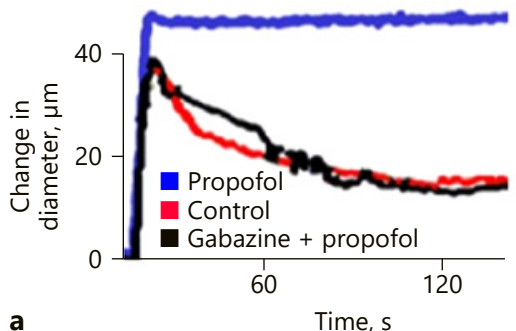

a

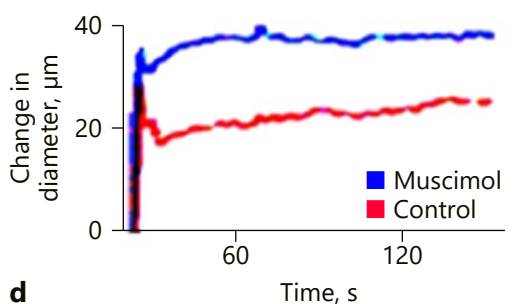

d

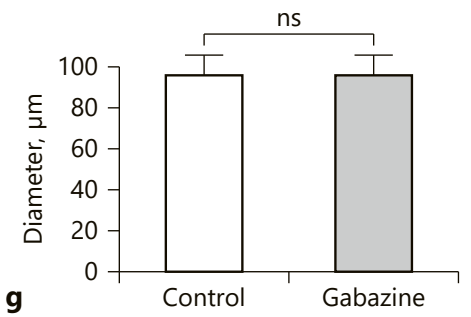

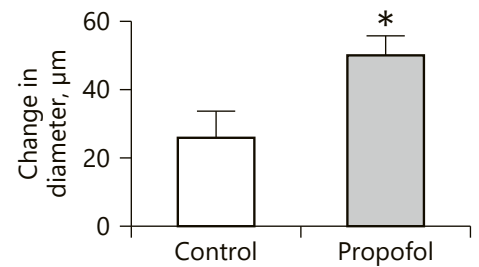

b

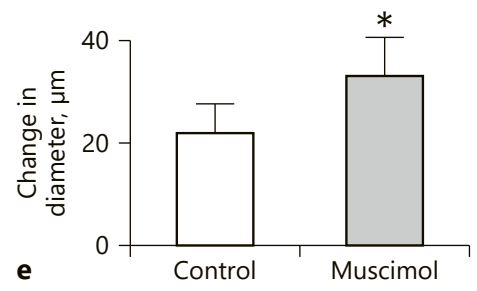

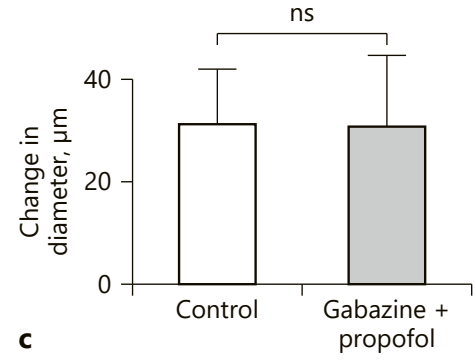

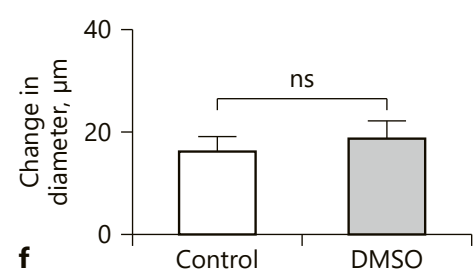

Fig. 4. a Representative vessel diameter tracings recorded during pressure myography in mouse tail resistance arteries. Pressure was raised from 0 to $90 \mathrm{~mm} \mathrm{Hg}$, which induced an initial dilation that induced a contraction (myogenic tone) as demonstrated in the control (buffer solution alone) tracing. Propofol pretreatment inhibited myogenic tone resulting in increased dilation. The $\mathrm{GABA}_{\mathrm{A}}$ antagonist gabazine antagonized the propofol dilatory effects, resulting in a control level of myogenic tone. b Quantitative analysis of myogenic tone expressed as a change in vessel diameter. In control studies, a 0 - to $90-\mathrm{mm} \mathrm{Hg}$ intraluminal pressure challenge resulted in a mean $( \pm$ SEM) diameter change of $26 \pm 7.4 \mu \mathrm{m}$, while propofol pretreatments blocked myogenic tone, resulting in vasodilation and a larger change in vessel diameter $(50 \pm 5.8 \mu \mathrm{m}$ [mean $\left.\pm \mathrm{SEM}] ;{ }^{*} p<0.05 ; n=3\right)$. c Co-pretreatment with propofol and the $\mathrm{GABA}_{\mathrm{A}}$ antagonist gabazine resulted in a change in vessel diameter $(30 \pm 5.8 \mu \mathrm{m})$ that was not different from the control $(31 \pm$

$\mathrm{mM}$. This resulted in an equalization of the electrochemical gradient for chloride and a loss of muscimol-induced current ( $p<0.05$ compared to muscimol alone; $n=3$; Fig. $3 b, c)$.

Functional GABA $\mathrm{G}_{\mathrm{A}}$ Receptors on Resistance Arteries
$10 \mu \mathrm{m}$ ), indicating that the propofol inhibition of myogenic tone is $\mathrm{GABA}_{\mathrm{A}}$ mediated ( $n s ; n=3$ ). $\mathbf{d}$ Representative vessel diameter tracings during pressure myography in MTA $(0-90 \mathrm{~mm} \mathrm{Hg})$. Muscimol pretreatment inhibited myogenic tone and increased vessel dilation. e Quantitative analysis of myogenic tone under control conditions demonstrated a vessel diameter change of $22 \pm 5.6 \mu \mathrm{m}$. The $\mathrm{GABA}_{\mathrm{A}}$ agonist muscimol inhibited myogenic tone, resulting in an increased vessel diameter of $33 \pm 7.5 \mu \mathrm{m}\left({ }^{*} p<0.05 ; n=3\right)$. f Results demonstrating no significant difference (ns; $n=3$ ) between $0.1 \%$ DMSO $(19 \pm 3.6 \mu \mathrm{m})$ and the control (buffered solution alone, $16 \pm 2.8 \mu \mathrm{m}$ ) on myogenic tone generation. $\mathbf{g}$ Effects of gabazine alone on baseline tone at $90 \mathrm{~mm} \mathrm{Hg}$. Gabazine treatment demonstrated no significant change to baseline tone $(94.8 \pm 11.4$ $\mu \mathrm{m})$ at $90 \mathrm{~mm} \mathrm{Hg}(\mathrm{ns} ; n=3)$ when compared to the control (buffered solution alone, $95.1 \pm 10.5 \mu \mathrm{m})$.

\section{$G A B A_{A}$ Ligands Decreased Myogenic Tone in Mouse Tail Resistance Artery}

In order to study the physiologic effects of $\mathrm{GABA}_{\mathrm{A}}$ activation in intact vessels, resistance artery myogenic tone studies were performed using pressure myography. Under 
Fig. 5. a Representative diameter tracings recorded during pressure myography in human omental resistance arteries. Intraluminal pressure was increased from 0 to 120 $\mathrm{mm} \mathrm{Hg}$, inducing an initial dilation that induced a control contraction (myogenic tone). Muscimol, a $\mathrm{GABA}_{\mathrm{A}}$-specific agonist, pretreatment inhibited myogenic tone and increased vessel dilation. b Quantitative analysis of myogenic tone under control conditions demonstrated a vessel diameter change of $38 \pm 0.7 \mu \mathrm{m}$ (mean \pm SEM). The $\mathrm{GABA}_{\mathrm{A}}$ agonist muscimol inhibited myogenic tone, resulting in an increased vessel size $\left(42 \pm 0.7 \mu \mathrm{m} ;{ }^{*} p<0.05 ; n=3\right)$.

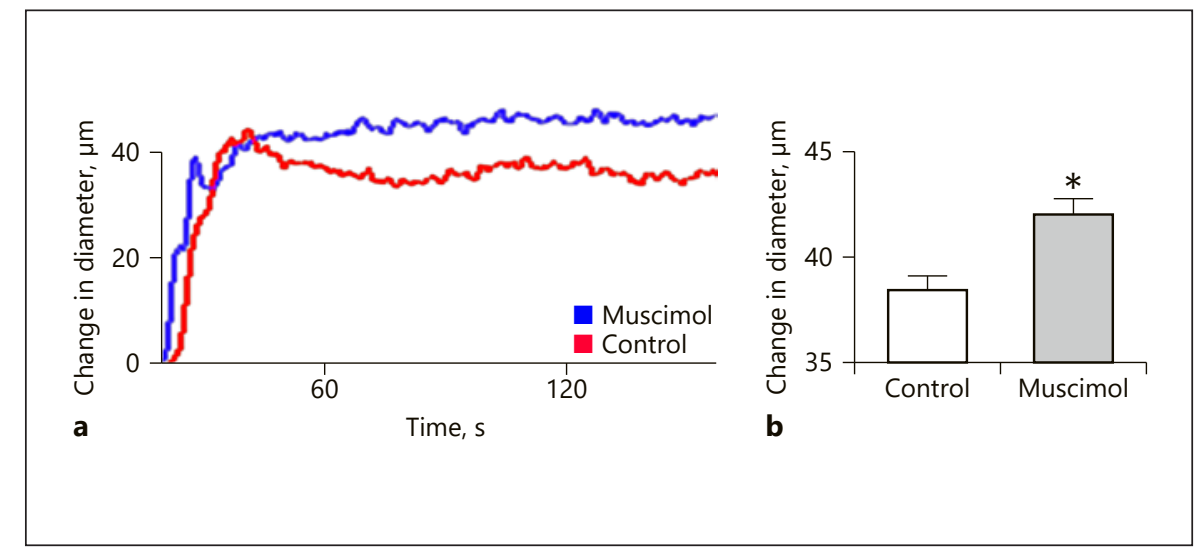

control conditions (buffer alone), mouse tail resistance arteries demonstrated myogenic tone when challenged with an increase in intraluminal pressure from 0 to $90 \mathrm{~mm} \mathrm{Hg}$ (Fig. $4 \mathrm{a})$. The addition of propofol $(0.1 \mu \mathrm{M})$ to the buffer superfusing the arterial segment decreased myogenic tone, resulting in an increased dilation $(p<0.05 ; n=3$; Fig. $4 a, b)$. The inhibition of myogenic tone by propofol was reversed by the addition of $100 \mu \mathrm{M}$ gabazine, a GA$\mathrm{BA}_{\mathrm{A}}$-specific inhibitor $(p>0.05 ; n=3)$, resulting in myogenic tone that was not significantly different from the control (ns; $n=3$; Fig. 4a, c), indicating that the propofol inhibition of myogenic tone is $\mathrm{GABA}_{\mathrm{A}}$ mediated.

To further prove that $\mathrm{GABA}_{\mathrm{A}}$ activation reduces myogenic tone, the $\mathrm{GABA}_{\mathrm{A}}$ agonist muscimol $(100 \mu \mathrm{M})$ was added to the buffer superfusing the MTA before the change in the intraluminal pressure from 0 to $90 \mathrm{~mm} \mathrm{Hg}$. Muscimol inhibited myogenic tone, resulting in an increased diameter change, which was significantly dilated compared to the control (buffered solution alone; Fig. 4d, e; $n=3$ ). Time controls were performed to demonstrate a maintenance of myogenic responses between the 3rd rise in intraluminal pressure and the 6th rise in intraluminal pressure. No significant differences were found between the 3 rd pressure cycle and the 6 th pressure cycle in the presence of $0.1 \%$ DMSO vehicle control (Fig. 4f). A gabazine control was performed by measuring the diameter change at $90 \mathrm{~mm} \mathrm{Hg}$ before and after $100 \mu \mathrm{M}$ gabazine was added. There was no significant change in the plateau phase of the myogenic response after gabazine treatment (Fig. 4g).

The GABA ${ }_{A}$ Agonist Muscimol Decreased Myogenic

Tone in Human Omental Resistance Arteries

To determine whether the effects of $\mathrm{GABA}_{\mathrm{A}}$ activation demonstrated in mouse arteries are also present in hu- man resistance arteries, myogenic tone studies were performed with freshly isolated human omental resistance arteries. Myogenic tone under control conditions (buffered solution alone) demonstrated myogenic function following an increase in intraluminal pressure from 0 to $120 \mathrm{~mm} \mathrm{Hg}$. Pretreatment of human vessels with muscimol $(100 \mu \mathrm{M})$ inhibited myogenic tone, resulting in an increased vessel dilation ( $p<0.05 ; n=3$; Fig. $5 \mathrm{a}, \mathrm{b})$.

\section{Discussion}

The primary findings of the present study are: (1) GA$\mathrm{BA}_{\mathrm{A}}$ subunits are expressed on smooth muscle cells from small-caliber murine vessels and human resistance arteries; (2) targeting of $\mathrm{GABA}_{\mathrm{A}}$ receptors on human resistance arterial smooth muscle modulates plasma membrane potential; and (3) myogenic tone is inhibited by $\mathrm{GABA}_{\mathrm{A}}$ agonists in whole tissue models. In VSM, myogenic tone is a contractile mechanism that is directly controlled by membrane potential and depolarization. When certain smallcaliber arteries are faced with increased intraluminal pressure, stretch-induced cation channels depolarize the VSM leading to activation of voltage-dependent calcium channels and TRP channels, resulting in calcium influx and a concomitant increase in intrinsic VSM tone [28-30]. Studies have demonstrated that the amount of depolarization in VSM directly correlates to the amount of calcium influx and the myogenic tone generated [29]. Given this established relationship between membrane depolarization and myogenic tone, we utilized an ex vivo myogenic tone model as the physiologic correlate to explore the influences of $\mathrm{GABA}_{\mathrm{A}}$ channel activation on voltage-dependent VSM tone. These studies describe for the first time $\mathrm{GABA}_{\mathrm{A}}$-mediated decreases of myogenic tone in human vessels. 
Myogenic tone is a property specific to small resistance arteries and increased myogenic tone is associated with an overall increased contractility of the VSM. When the luminal pressure increases, a myogenic response is initiated, which leads to vessel constriction to maintain a constant flow through the arteries. During pathologic states, such as hypertension, resistance arteries demonstrate an increase in myogenic tone in the cerebral and skeletal muscle vasculature [31-33]. However, the distinct pathophysiologic role of myogenic tone in hypertension is not well defined. Not all animal models of hypertension consistently show enhanced myogenic tone. In the rat model of sodium intake-induced hypertension, there seems to be a decrease in myogenic tone [34]. In contrast, in the spontaneously hypertensive rat model, myogenic tone is increased in certain vascular beds [31-33]. The mechanisms that allow the cardiovascular system to compensate and modulate their myogenic tone may have influence over normal physiology and pathophysiology. By demonstrating the effects of GA$\mathrm{BA}_{\mathrm{A}}$ activation on myogenic tone, we implicate a possible mechanism of endogenous vascular modulation of myogenic tone since GABA circulates in blood and many peripheral cells are capable of synthesizing GABA. The effect of $\mathrm{GABA}_{\mathrm{A}}$ on vascular biology will require further studies in order to fully determine the role that GABA plays in vascular physiology and the potential therapeutic value of GABAergic targeting. In the current study, resistance vessels from human omentum were used as a model of myogenic tone. In order to make further conclusions on blood pressure regulation and the pathogenesis or treatment of hypertension, studies on other vascular tissue from other regions (i.e., mesenteric and renal) will need to be performed, recovered from patients carefully clinically phenotyped with regard to their cardiovascular status.

Since $\mathrm{GABA}_{\mathrm{A}}$ ligand selectivity is largely determined by the a subunit composition of the $\mathrm{GABA}_{\mathrm{A}}$ receptor, we performed RT-PCR analysis using LCMD to obtain discrete areas of smooth muscle from mouse tail and human omental resistance arteries. We detected mRNA encoding the $\alpha 3, \alpha 4, \beta 2, \gamma 2$, and $\delta \mathrm{GABA}_{\mathrm{A}}$ subunits in VSM, while mRNA encoding for other $\mathrm{GABA}_{\mathrm{A}}$ subunits were not detected ( $\alpha 1, \alpha 2, \alpha 5, \alpha 6, \beta 1, \beta 3, \gamma 1$, and $\left.\gamma_{3}\right)$. These results demonstrate an expression profile of GA$\mathrm{BA}_{\mathrm{A}} \alpha, \beta$, and $\delta / \gamma$ subunits in a sufficient repertoire needed to form a classic functional $\mathrm{GABA}_{\mathrm{A}}$ receptor. Data from RT-PCR analysis revealed that the specific a subunit composition of VSM GABA $(\alpha 4, \alpha 3)$ receptors did not include the predominant subunits found in the
CNS $(\alpha 1, \alpha 2)$, but rather an expression profile more consistent with extrasynaptic/peripheral $\mathrm{GABA}_{\mathrm{A}}$ receptors [35]. Extrasynaptic $\mathrm{GABA}_{\mathrm{A}}$ channels are characteristically responsive to lower concentrations of GABA and display slower desensitization properties (collectively termed "tonic") [36]. This current study describes the novel mRNA expression profile of the $\mathrm{GABA}_{\mathrm{A}}$ receptor subunits on VSM. Further studies need to be performed to further demonstrate the protein expression profile to fully correlate with the mRNA expression profiles and to understand the possible subunit stoichiometry of these expressed subunits.

Primary VSM cells loaded with a potentiometric fluorescent indicator demonstrated an increased fluorescence in the presence of propofol, a widely used clinical GABAergic anesthetic. Propofol had a greater depolarization effect on VSM than a classic $\mathrm{GABA}_{\mathrm{A}}$ agonist, muscimol. Previous studies have demonstrated that propofol causes a variety of molecular and physiologic responses in VSM cells other than $\mathrm{GABA}_{\mathrm{A}}$ activation, such as increases in smooth muscle TRP channel activation and modulation of VSM calcium at higher concentrations $[37,38]$. To further specify and quantify the electrophysiologic response of $\mathrm{GABA}_{\mathrm{A}}$ activation on resistance artery physiology, intracellular current recordings were performed using the $\mathrm{GABA}_{\mathrm{A}}$-specific agonist muscimol on individual VSM cells. This demonstrated an inward current at negative membrane potential, and a loss of that current in the presence of a $\mathrm{GABA}_{\mathrm{A}}$-specific inhibitor or a decreased chloride gradient $(10 \mathrm{mM}$ chloride in internal solution).

Only $10 \%$ of the smooth muscle had responses to GABA agonist exposure in the patch clamp system, while global measurements of the potentiometric indicator in a monolayer of cells revealed a more robust response. This is likely due to the potentiometric indicator allowing for the measurement of fluorescence changes within the entire field of cells in a 96-well plate, while the automated patch system measures a single cell in a dispersed culture. Cells grown to confluence in culture allows for cell to cell interactions such as gap junction formation. This GABA responsive subpopulation may also give rise to the possibility that there is differential expression within the VSM itself.

We further demonstrated that $\mathrm{GABA}_{\mathrm{A}}$ activators decreased the calcium responses elicited by endothelin. We demonstrated that at a membrane potential of -80 $\mathrm{mV}$ an inward current is elicited by a $\mathrm{GABA}_{\mathrm{A}}$ receptor agonist. With an electrochemical equilibrium that is estimated at $-40 \mathrm{mV}$ in systemic arteries [39], a tonic chlo- 
ride flux through $\mathrm{GABA}_{\mathrm{A}}$ receptors would prevent the full activation of membrane potential gated channels, normally around $20 \mathrm{mV}$, and inhibit calcium entry through voltage-regulated calcium channels. Further studies demonstrating in situ tissue recordings will be needed to fully elucidate the mechanism of $\mathrm{GABA}_{\mathrm{A}}$-mediated loss of myogenic tone.

In conclusion, we have described the subunit expression profile of $\mathrm{GABA}_{\mathrm{A}}$ receptors in resistance arterial VSM cells. Furthermore, we demonstrated that the GA$\mathrm{BA}_{\mathrm{A}}$ a 4 subunit protein is contained within the VSM layer of the resistance artery. We elicited a functional $\mathrm{GABA}_{\mathrm{A}}$ channel response by demonstrating the ability of the receptor to cause a membrane potential change when activated by a $\mathrm{GABA}_{\mathrm{A}}$-specific agonist. We demonstrated a physiologic response to the membrane potential changes caused by the $\mathrm{GABA}_{\mathrm{A}}$ activation in ex vivo myogenic tone studies in human and mouse resistance arteries. These studies indicate that functional $\mathrm{GABA}_{\mathrm{A}}$ receptors exist on resistance arteries and may be a viable therapeutic target for the treatment of hypertension.

\section{Acknowledgements}

We express our thanks to Nick Flavahan and Sheila Flavahan.

\section{Statement of Ethics}

All animal studies were approved by IACUC. All human tissue studies were deemed non-human subject research by the IRB of Columbia University.

\section{Disclosure Statement}

The authors have no conflicts of interest to disclose.

\section{Funding Sources}

Foundation for Anesthesiology Research and Education, Mentored Research Training Grant (P.D.Y.), National Institutes of Health grants GM065281 (C.W.E.), HL122340 (C.W.E.), HD082251 (G.G.), and HL124213 (D.E.B.).

\section{Author Contributions}

Peter D. Yim wrote the manuscript and was involved in the design, performance, and analysis of all the studies. George Gallos was involved in study design, analysis of data, and editing of the paper. Steven Lee-Kong was involved in the performance and study design of all human tissue studies. Dingbang Xu performed studies, analyzed data, and wrote sections of the manuscript. Dan E. Berkowitz and Charles W. Emala were involved in study design, analysis of data, and editing of the manuscript. William Dan edited the text and figures, as well as performing/designing the experiments. Amy $\mathrm{Wu}$ was involved in writing and editing of the figures, as well as performing the experiments.

\section{References}

1 Hajjar I, Kotchen TA. Trends in prevalence, awareness, treatment, and control of hypertension in the United States, 1988-2000. JAMA. 2003 Jul;290(2):199-206.

2 Nwankwo T, Yoon SS, Burt V, Gu Q. Hypertension among adults in the United States: National Health and Nutrition Examination Survey, 2011-2012. NCHS Data Brief. 2013 Oct; $133: 1-8$.

3 Mozaffarian D, Benjamin EJ, Go AS, Arnett DK, Blaha MJ, Cushman M, et al.; American Heart Association Statistics Committee and Stroke Statistics Subcommittee. Heart disease and stroke statistics -2015 update: a report from the American Heart Association. Circulation. 2015 Jan;131(4):e29-322.

4 Huang A, Sun D, Koller A. Endothelial dysfunction augments myogenic arteriolar constriction in hypertension. Hypertension. 1993 Dec;22(6):913-21.

5 Izzard AS, Rizzoni D, Agabiti-Rosei E, Heagerty AM. Small artery structure and hypertension: adaptive changes and target organ damage. J Hypertens. 2005 Feb;23(2):247-50.
6 van den Akker J, Schoorl MJ, Bakker EN, Vanbavel E. Small artery remodeling: current concepts and questions. J Vasc Res. 2010; 47(3):183-202.

7 Sandström K, Wallerstedt SM, Tornebrandt $\mathrm{K}$, Bodelsson M. Effects of propofol on desipramine-sensitive $[3 \mathrm{H}]$-noradrenaline uptake kinetics in rat femoral artery. Acta Anaesthesiol Scand. 2000 Sep;44(8):1011-6.

8 Shirasaka T, Yoshimura Y, Qiu DL, Takasaki M. The effects of propofol on hypothalamic paraventricular nucleus neurons in the rat [table of contents.]. Anesth Analg. 2004 Apr; 98(4):1017-23.

9 Ma P, Li T, Ji F, Wang H, Pang J. Effect of GABA on blood pressure and blood dynamics of anesthetic rats. Int J Clin Exp Med. 2015 Aug;8(8):14296-302.

10 French JF, Rapoport RM, Matlib MA. Possible mechanism of benzodiazepine-induced relaxation of vascular smooth muscle. J Cardiovasc Pharmacol. 1989 Sep;14(3):405-11.

11 MacPherson RD, Rasiah RL, McLeod LJ. Propofol attenuates the myogenic response of vascular smooth muscle. Anesth Analg. 1993 Apr;76(4):822-9.
12 Samain E, Clichet A, Bouillier H, ChamiotClerc P, Safar M, Marty J, et al. Propofol differently alters vascular reactivity in normotensive and hypertensive rats. Clin Exp Pharmacol Physiol. 2002 Nov;29(11):1015-7.

13 Moriyama T, Tsuneyoshi I, Kanmura Y. Effects of a novel benzodiazepine derivative, JM-1232(-), on human gastroepiploic artery in vitro. J Cardiothorac Vasc Anesth. 2011 Feb;25(1):72-7.

14 Kamran M, Bahrami A, Soltani N, Keshavarz M, Farsi L. GABA-induced vasorelaxation mediated by nitric oxide and GABAA receptor in non diabetic and streptozotocin-induced diabetic rat vessels. Gen Physiol Biophys. 2013 Mar;32(1):101-6.

15 Mizuta K, Xu D, Pan Y, Comas G, Sonett JR, Zhang Y, et al. GABAA receptors are expressed and facilitate relaxation in airway smooth muscle. Am J Physiol Lung Cell Mol Physiol. 2008 Jun;294(6):L1206-16.

16 Mortensen M, Patel B, Smart TG. GABA potency at $\mathrm{GABA}(\mathrm{A})$ receptors found in synaptic and extrasynaptic zones. Front Cell Neurosci. 2012 Jan;6:1. 
17 Gallos G, Gleason NR, Zhang Y, Pak SW, Sonett JR, Yang J, et al. Activation of endogenous GABAA channels on airway smooth muscle potentiates isoproterenol-mediated relaxation. Am J Physiol Lung Cell Mol Physiol. 2008 Dec;295(6):L1040-7.

18 Gallos G, Gleason NR, Virag L, Zhang Y, Mizuta K, Whittington RA, et al. Endogenous gamma-aminobutyric acid modulates tonic guinea pig airway tone and propofol-induced airway smooth muscle relaxation. Anesthesiology. 2009 Apr;110(4):748-58.

19 Gleason NR, Gallos G, Zhang Y, Emala CW. The GABAA agonist muscimol attenuates induced airway constriction in guinea pigs in vivo. J Appl Physiol. 2009 Apr;106(4):125763.

20 Gallos G, Townsend E, Yim P, Virag L, Zhang $\mathrm{Y}, \mathrm{Xu} \mathrm{D}$, et al. Airway epithelium is a predominant source of endogenous airway GABA and contributes to relaxation of airway smooth muscle tone. Am J Physiol Lung Cell Mol Physiol. 2013 Feb;304(3):L191-7.

21 Gallos G, Yocum GT, Siviski ME, Yim PD, Fu $\mathrm{XW}$, Poe MM, et al. Selective targeting of the a5-subunit of GABAA receptors relaxes airway smooth muscle and inhibits cellular calcium handling. Am J Physiol Lung Cell Mol Physiol. 2015 May;308(9):L931-42.

22 Forkuo GS, Guthrie ML, Yuan NY, Nieman AN, Kodali R, Jahan R, et al. Development of GABAA receptor subtype-selective imidazobenzodiazepines as novel asthma treatments. Mol Pharm. 2016 Jun;13(6):2026-38.

23 Yocum GT, Gallos G, Zhang Y, Jahan R, Stephen MR, Varagic $Z$, et al. Targeting the $\gamma$-aminobutyric acid A receptor a4 subunit in airway smooth muscle to alleviate bronchoconstriction. Am J Respir Cell Mol Biol. 2016 Apr;54(4):546-53.
24 Kublickiene K-R, Kublickas M, Lindblom B, Lunell N-O, Nisell H. A comparison of myogenic and endothelial properties of myometrial and omental resistance vessels in late pregnancy. Am J Obstet Gynecol. 1997; 176(3):560-6

25 Veerareddy S, Cooke CL, Baker PN, Davidge ST. Vascular adaptations to pregnancy in mice: effects on myogenic tone. Am J Physiol Heart Circ Physiol. 2002 Dec;283(6):H222633.

26 Coats P. Myogenic, mechanical and structural characteristics of resistance arterioles from healthy and ischaemic subjects. Clin Sci. 2003 Dec;105(6):683-9.

27 Clifford PS. Local control of blood flow. Adv Physiol Educ. 2011 Mar;35(1):5-15.

28 Jackson WF. Ion channels and vascular tone. Hypertension. 2000 Jan;35(1 Pt 2):173-8.

29 Schubert R, Brayden JE. Stretch-activated cation channels and the myogenic response of small arteries. In: Kamkin A, Kiseleva I, editors. Mechanosensitivity in cells and tissues. Moscow: Academia; 2005.

30 Ji L, Zhu H, Chen H, Fan W, Chen J, Chen J, et al. Modulation of CaV1.2 calcium channel by neuropeptide $\mathrm{W}$ regulates vascular myogenic tone via $\mathrm{G}$ protein-coupled receptor 7 . J Hypertens. 2015 Dec;33(12):2431-42.

31 Falcone JC, Granger HJ, Meininger GA. Enhanced myogenic activation in skeletal muscle arterioles from spontaneously hypertensive rats. Am J Physiol. 1993 Dec;265(6 Pt 2):H1847-55.

32 Garcia SR, Izzard AS, Heagerty AM, Bund SJ. Myogenic tone in coronary arteries from spontaneously hypertensive rats. J Vasc Res. 1997 Mar-Apr;34(2):109-16.
33 Jiménez-Altayó F, Martín A, Rojas S, Justicia C, Briones AM, Giraldo J, et al. Transient middle cerebral artery occlusion causes different structural, mechanical, and myogenic alterations in normotensive and hypertensive rats. Am J Physiol Heart Circ Physiol. 2007 Jul;293(1):H628-35.

34 Matrougui K, Loufrani L, Lévy BI, Henrion D. High $\mathrm{NaCl}$ intake decreases both flow-induced dilation and pressure-induced myogenic tone in resistance arteries from normotensive rats: involvement of cyclooxygenase-2. Pharmacol Toxicol. 2001 Oct;89(4): $183-7$.

35 Roberts DS, Hu Y, Lund IV, Brooks-Kayal AR, Russek SJ. Brain-derived neurotrophic factor (BDNF)-induced synthesis of early growth response factor 3 (Egr3) controls the levels of type A GABA receptor alpha 4 subunits in hippocampal neurons. J Biol Chem. 2006 Oct;281(40):29431-5.

36 Rabow LE, Russek SJ, Farb DH. From ion currents to genomic analysis: recent advances in GABAA receptor research. Synapse. 1995 Nov;21(3):189-274

37 Fassl J, High KM, Stephenson ER, Yarotskyy $\mathrm{V}$, Elmslie KS. The intravenous anesthetic propofol inhibits human L-type calcium channels by enhancing voltage-dependent inactivation. J Clin Pharmacol. 2011 May;51(5): 719-30.

38 Sinha S, Sinharoy P, Bratz IN, Damron DS. Propofol causes vasodilation in vivo via TRPA1 ion channels: role of nitric oxide and BKCa channels. PLoS One. 2015 Apr; 10(4):e0122189.

39 Kitamura K, Yamazaki J. Chloride channels and their functional roles in smooth muscle tone in the vasculature. Jpn J Pharmacol. 2001 Apr;85(4):351-7. 